\title{
ECONOMIC EFFECTS OF QUALITY REGULATIONS IN THE DAYCARE INDUSTRY
}

Tasneem Chipty

Ann Dryden Witte

Working Paper No. 4953

\section{NATIONAL BUREAU OF ECONOMIC RESEARCH 1050 Massachusetts Avenue \\ Cambridge, MA 02138 \\ December 1994}

We thank Ellen Kisker and Sandra Hofferth for assistance. Witte's work on this project was supported by a grant from the National Science Foundation (NSF). NSF's support for the project in no way implies support for our methods or conclusions. All errors are our own. This paper is part of NBER's research programs in Labor Studies and Public Economics. Any opinions expressed are those of the authors and not those of the National Bureau of Economic Research.

() 1994 by Tasneem Chipty and Ann Dryden Witte. All rights reserved. Short sections of text, not to exceed two paragraphs, may be quoted without explicit permission provided that full credit, including () notice, is given to the source. 


\title{
ECONOMIC EFFECTS OF \\ QUALITY REGULATIONS IN THE \\ DAYCARE INDUSTRY
}

\begin{abstract}
We estimate reduced form models to discern the effect of state regulation of the quality of center and family day care. Specifically, we consider the effects of the number of mandated inspections, limits on group size and staff/child ratio, and staff training requirements on equilibrium price and hours of care and the quality of care as measured by the actual staff/child ratio. The specification of the reduced form model is derived from an eight equation market model for wages and work hours, type of child care chosen, price and hours of care and a set of hedonic equations for the characteristics of care.

The results indicate strongly that child care regulations do affect equilibrium price, hours of care, and staff/child ratios. Child care regulations are binding. In equilibrium, only regulations regarding staff training appear to have consistently desirable effects. Such regulations decrease equilibrium price and hours of care and increase the staff/child ratio for both centers and family day care. Regulations of group size and the staff/child ratio have significant effects, but the welfare implications of the effects are more ambiguous.
\end{abstract}

Tax deductions and subsidies for child care have similarly ambiguous welfare effects. For example, households that take a tax deduction for child care pay higher prices for care, consume more hours of care and consume higher quality day care.

Tasneem Chipty

Department of Economics

Ohio State University

410 Arps Hall

Columbus, $\mathrm{OH} 43210$
Ann Dryden Witte Department of Economics Wellesley College Wellesley, MA 02181-8260 and NBER 


\section{Economic Effects of Quality Regulations in the Day Care Industry}

Tasneem Chipty and Ann Dryden Witte

With the heightened demand for day care in the United States has come a growing concern with the quality of provision. Purchasers, who are generally the parents of the child, find it difficult to assess the quality of care. In addition, the social consequences of poor quality day care are potentially grave.

Public intervention in day care markets might be justified either using arguments commonly made for the public provision of education or using arguments regarding imperfect information. State regulators, recognizing both the information and the public good problems, have imposed various minimum quality standards on day care providers. Little is known, however, about the effectiveness of these regulations.

In this paper, we exploit the cross-state variation in the choice and intensity of regulations to identify the effect of regulation on market performance. Using data from the 1990 National Child Care Survey, we estimate the impact of state-imposed quality regulations on equilibrium market prices, quantities, and quality. We find that regulations are binding on day care providers; that is, minimum quality requirements do have economically large and statistically significant effects on equilibrium prices, quantities, as measured by hours, and quality, as measured by staff/child ratios. Further, the results indicate that certain types of regulations are more effective than others at raising equilibrium product quality.

In the next section, we describe the provision of day care. In Section 3, we describe our data and Section 4 contains our empirical specification. In Section 5 we discuss our results and the final section contains our conclusions.

\section{The Day Care Industry}

The increase in female labor force participation has resulted in increased use of adults outside the immediate family to care for children. The non-parental, non-relative child care settings chosen most often are family day care and center day care. In 1985, a little more than 
$50 \%$ of all children under the age of 5 , whose mothers worked outside the home, were cared for by nonrelatives. Of these $50 \%$, only $6 \%$ were cared for in the child's own home. The remaining $44 \%$ were cared for outside of the child's home in either day care centers, family day care homes, nursery schools, prekindergarten, kindergarten, before and after school programs, or Headstart programs. Ninety percent of the children cared for outside their homes were in day care centers and family day care homes.

Family day care homes and day care centers are two quite different entities (Adams [1990], Hayes, et al. [1990], Morgan [1986]), which face different regulations. For example, centers care for large numbers of children in institutional settings while family day care home care for only three or four children in a home setting. Family day care homes are owner operated while centers come in a wide variety of institutional forms (e.g, corporate chains such as Kinde Care, non-for-profit entities). Centers group children according to age, while family providers mix children of all ages. Family providers tend to care primarily for very young children, while centers tend to care for preschoolers. The two types of day care also face different regulations. For example, both staff/child ratio and group size are regulated for centers while only group size is regulated for family day care homes.

Since 1982, states have had the primary responsibility for the regulation of day care. States generally regulate only family day care and center day care. Over the last decade, regulations everywhere have become more stringent, though states vary dramatically in their specific provisions. Regulations may specify the number of mandated annual inspections, maximum group size limits, and training requirements for caregivers. They may also include health and safety rules, such as physical space and immunization requirements. Regulations for centers may also specify minimum staff/child ratios.

Very little is known about the effectiveness and impact of day care regulations. The work that has been done finds limited (Gormley [1991]) if any (Hofferth and Wissoker [1992]) effect of regulations on economic outcomes. It has been suggested that day care regulations are not binding since enforcement efforts are weak. If the regulatory requirements are not binding, it is not surprising that they have no significant effect on economic outcomes. Alternatively, if the requirements do bind, we then need to determine their economic impact. From a policy perspective, we need ultimately to ascertain which regulations are better at enhancing social 
surplus. Our primary objective, in this paper, is to address the first, basic question: do the regulations bind?

\section{Data}

We use household level survey data from the 1990 National Child Care Survey (NCCS). The NCCS interviewed a stratified random sample of US households with at least one child less than 13 years old. The survey collected detailed information on the child's day care schedule, including hours spent at each arrangement, cost of each arrangement, and the staff/child ratio at each arrangement; the parents' work schedule; and various other family characteristics. See Hofferth, et al. [1991] for details regarding the NCCS. In addition to the NCCS data, we employ county level local demographic information from the 1988 City and County Data Book. Finally, state level regulatory requirements were compiled from Adams [1990], Hayes, et al. [1990] and Morgan [1986].

We study the effects of regulatory requirements on the equilibrium prices paid, hours used, and staff/child ratios faced by households using center care and family day care. Table 1 contains descriptive statistics for the variables employed in the paper.

\section{Empirical Specification}

We develop and specify a structural model of day care market, which provides a theoretical underpinning for the reduced form equations that we estimate. ${ }^{1}$ Day care outcomes result from a complex set of family and provider decisions. Family labor market decisions are inextricably linked with day care choices. Day care choices are complex because they involve both a choice of care and a choice of the characteristics of care. We adopt a standard labor market model, a type of care choice model that builds on previous work such as that of Hofferth and Wissoker [1992] and a hedonic model that extends work by Walker [1992] and is based on Epple [1987].

${ }^{1}$ See Hayes, et al. for a survey of the literature and the Winter, 1992 special issue of the Journal of Human Resources for recent work by economists. 
We detail seven structural equations that provide a basis for specifying the reduced forms we estimate. The equations are : day care supply $\left(D^{S}\right)$, day care demand $\left(D^{D}\right)$, labor supply $\left(L^{S}\right)$, labor demand $\left(L^{D}\right)$, supply of care characteristics $\left(\right.$ CARECHAR ${ }^{S}$ ), demand for care characteristics (CARECHAR ${ }^{\mathrm{D}}$ ), and the choice of care type equation (TYPE).

The day care supply and demand equations are given below:

$$
\begin{gathered}
D^{D}: \text { HOURS }_{D}=f_{1}\left(\text { PRICE }_{D}, \text { HOURS }_{\text {W FAMCHAR, CHILDCHAR, AVAILABILITY })}\right. \\
D^{S}: \text { PRICE }_{D}=f_{2}\left(\text { HOURS }_{D}, \text { TYPE }, \text { CHIDCHAR, CARECHAR, AVAILABILITY },\right. \\
\text { LOCAREA, REGS })
\end{gathered}
$$

where $\mathrm{PRICE}_{\mathrm{D}}$ is the weekly price for day care; HOURS $\mathrm{D}_{\mathrm{D}}$ is the weekly hours of day care; HOURS $_{\mathrm{w}}$ is hours worked by the individual primarily responsible for the child; FAMCHAR is a vector of family characteristics which include the natural log of family income (LNFAMINC), total number of children in the family below age 13 (TOTKIDS13); an indicator variable for whether the family takes a tax deduction for day care (TAXDED), and an indicator variable for whether the family receives a child care subsidy (SUBSIDY); CHILDCAR is a vector of the child's characteristics which include the age of the child (AGE), an indicator variable for whether the child is a newborn (NEWBORN), and an indicator variable for whether the child is currently in school (SCHOOL); AVAILABILITY is a vector of measures reflecting the availability of various types of child care, which includes the ratio of number of centers in the state to the population of individuals under 14 years of age (CENTERS/KIDPOP), and the ratio of the number of family providers in the state to the population of individuals under 14 years of age (FAMILY/KIDPOP), and an indicator variable for whether there is a relative available for child care (RELNEAR); TYPE is a discrete variable which describes the type of care chosen, i.e. center, family, relative, nanny, etc.; CARECHAR is a vector of care characteristics which include an indicator variable for whether or not the caregiver is trained in child psychology or early-childhood education (TRAINING), the staff/child ratio (STAFF/CHILD); LOCAREA is a vector of local area characteristics which include an indicator variable for whether the area is urban (URBAN), and the local unemployment rate (UNEMPRATE); and REGS is a vector of regulatory requirements which includes the number 
of annual inspections required by regulation (INSPECTIONS), the inverse of the maximum group size permitted (1/MXGRSZ), an indicator variable for whether training is required of the caregiver (RTRAINING), and the minimum staff/child ratio permitted (RSTAFF/CHILD).

The labor supply and demand equations are:

$$
\begin{aligned}
& L^{D}: \text { WAGES }=g_{1}\left(\text { HOURS }_{W} \text { RCHAR, LOCAREA }\right) \\
& L^{S}: \text { HOURS }_{W}=g_{2}\left(\text { WAGES, PRICE } E_{D}, \text { RCHAR, LOCAREA }\right)
\end{aligned}
$$

where WAGES is the market wage, RCHAR is a vector of the reference adult's characteristics which includes an indicator variable for whether the respondent is black (BLACK), a variable indicating whether the respondent is hispanic (HISPANIC), age (RAGE), years of education (EDUC), an indicator variable for whether the respondent is a manager, executive, or specialty professional (MANAG), years of work experience (EXPER); the other variables defined previously.

The next three equations are the hedonic model for the heterogeneous product child care. The first equation is the hedonic equation:

$$
\text { PRICE }_{D}=h(\text { CARECHAR })
$$

The derivatives of this equations provide implicit prices for the characteristics of child care.

The next two equations are the inverse supply and demand functions for the $i$ th characteristics of care:

$$
\begin{aligned}
& \text { CARECHAR }_{i}^{D}: h_{i}=h_{1}(\text { CARECHAR, RCHAR }) \\
& \text { CARECHAR }_{i}^{S}: h_{i}=h_{2}(\text { CARECHAR, TYPE, REGS })
\end{aligned}
$$

where $h_{i}$ is partial derivative of $h$ with respect to the $i$ th characteristic of care (Epple 1987).

The final equation is the choice of care equation:

$$
T Y P E=d\left(C A R E C H A R_{1}, . ., C A R E C H A R_{f}, W A G E S_{1}, \ldots, W A G E S_{s}, P R I C E_{D I}, . ., P R I C E_{D J}\right)
$$

where there are $\mathrm{J}$ types of care to choose from, and $\mathrm{CARECHAR}_{\mathrm{j}}$ are the care characteristics 


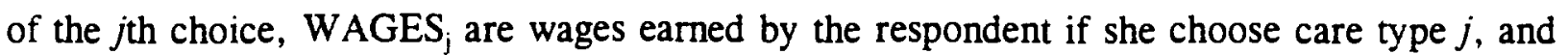
PRICE $_{D j}$ is the price of the $j$ th type of day care.

The endogenous variables in this system of equations are: WAGE, HOURS ${ }_{w}$, PRICE $_{\mathrm{D}}$, HOURS $_{\mathrm{D}}$, TYPE, and CARECHAR. The exogenous variables are: REGS, RCHAR, CHILDCAR, FAMCHAR, LOCAREA, and AVAILABILITY.

To determine whether existing state regulations are binding, we estimate the reduced form equations for PRICE $E_{D}$, HOURS ${ }_{D}$, and STAFF/CHILD implied by the structural system. The reduced form equations are:

$$
\begin{aligned}
Y_{j}= & \beta_{0 j}+R E G S \beta_{1 j}+R C H A R \beta_{2 j}+\text { CHILDCHAR } \beta_{3 j}+F A M C H A R \beta_{4 j}+ \\
& \text { LOCAREA } \beta_{5 j}+\text { AVAILABILITY } \beta_{6 j}+\epsilon_{j}
\end{aligned}
$$

where $j$ indexes the dependent variable; i.e., the dependent variable $\mathrm{Y}$ equals $\mathrm{PRICE}_{\mathrm{D}}$, HOURS $_{\mathrm{D}}$, and STAFF/CHILD when $j=1,2$, and 3, respectively. Parameters of equation (6) are estimated using ordinary least squares for each care type.

\section{Results}

Table 2 contains our results for the reduced form for the price of child care, the hours of care and the staff/child ratio. ${ }^{2}$ The explanatory variables explain sizeable portions of the variation in the dependent variables; the coefficients of determination range from 0.34 to 0.51 . The findings resoundingly indicate that regulations do indeed bind. In particular, we find that an increase in the number of mandated annual inspections significantly increases equilibrium prices and hours of day care consumed and significantly decreases the equilibrium staff/child ratio for both family and center care. Also, group size regulations become stricter, i.e. 1/MXGRSZ increases, equilibrium prices and quality increase and hours decrease for both family and center care. As training requirements increase, equilibrium prices and hours decrease, while equilibrium quality increases, for both types of care. Finally, minimum

2 Complete set of results omitted due to space constraints, but available upon request. 
staff/child ratio requirements significantly reduce price, hours, and quality.

Structural interpretation of these coefficients, while tempting to make, are impossible to infer from these reduced form estimates and remain for future work. These results do suggest, however, that there are tradeoffs in quality regulations. The group size requirements, for example, successfully increase equilibrium quality, but in the process, they raise equilibrium price and reduce equilibrium hours.

The results indicate that tax deductions, subsidies and family income significantly affect child care choices. Specifically, households that take a tax deduction for their day care expenditures pay higher prices for day care, consume more hours of day care, and consume higher quality day care. Higher family incomes lead to higher prices for child care and subsidies have significant but diverse effects depending on the type of care.

Finally, the results indicate, quite reasonably, that the availability of alternate forms of child care are important determinants of the equilibrium market outcomes. We find that increases in the competition, or availability, of both centers and family providers reduces the equilibrium price and increases the equilibrium hours of family daycare. However, an increase in the availability of centers does not have a statistically significant effect on the equilibrium prices and hours of center care. An increase in the availability of family providers increases equilibrium prices and hours of center care.

\section{Conclusions}

We find that state regulation of child care quality have significant effects on equilibrium price, quality and hours of care; that is, we find that regulations are binding. Our work moves the literature forward. While Gormley [1991] was able to use only data aggregated to the state level, we are able to use data on actual family decisions regarding both the labor market and child care. We build on work by Hofferth and Wissoker [1992]. We extend their work by developing a structural model, which provides a firmer base for specifying the reduced form equations. With the improved specification and improved data, we find strong effects for regulation.

Since we estimate only reduced form equations, we can make no inferences regarding the effects of regulations on the behavior of either demanders or suppliers. We see our work as 
a useful first step. The work strongly indicates that regulations significantly affect market equilibria. Clearly, the next step is to estimate the structural equations. Such estimates could provide valuable guidance for policy makers as they struggle with welfare reform, policies regarding subsidies and tax deductions for child care, and for states as they make decisions regarding the type of regulations to implement and the way in which to enforce the regulations adopted. 
Table 1: Variable Definitions and Means by Care Type

\begin{tabular}{|c|c|c|c|}
\hline Variable & Definition & Family & Center \\
\hline \multicolumn{4}{|c|}{ Dependent Variables } \\
\hline Price & Price per week for care of youngest child & 47.470 & 63.703 \\
\hline Hours & Hours per week of care & 33.371 & 36.897 \\
\hline Staff/Child & Staff/Child ratio & 0.506 & 0.206 \\
\hline \multicolumn{4}{|c|}{ Measures of Regulation } \\
\hline Inspections & Number of mandated inspections per year & 1.030 & 1.798 \\
\hline 1/Mrgrsz & Inverse of maximum group size permitted & 0.135 & 0.029 \\
\hline Rtraining & Dummy $=1$ if pre or in-service training required & 0.360 & 0.965 \\
\hline Rstaff/Child & Minimum required staff child ratio for the child's age group & & 0.101 \\
\hline \multicolumn{4}{|c|}{ Respondent's Characteristics } \\
\hline Black & Dummy $=1$ if black & 0.093 & 0.079 \\
\hline Hispanic & Dummy $=1$ if hispanic & 0.047 & 0.061 \\
\hline Rage & Age & 30.070 & 32.395 \\
\hline Educ & Years of education & 13.663 & 14.561 \\
\hline Manag & Dummy $=1$ if professional specialty occupation or manager & 0.058 & 0.184 \\
\hline Exper & Years of experience & 10.674 & 12.096 \\
\hline \multicolumn{4}{|c|}{ Child's Characteristics } \\
\hline Kage & Age & 2.465 & 2.939 \\
\hline Newborm & Dummy $=1$ if child is $<1$ year old & 0.186 & 0.105 \\
\hline School & Dummy $=1$ if child is in school & 0.163 & 0.105 \\
\hline \multicolumn{4}{|c|}{ Family and Local Area Characteristics } \\
\hline Faminc & Annual family income, in dollars & & \\
\hline Totkids 13 & Number of kids $<13$ years old in household & 1.988 & 1.991 \\
\hline Taxded & Dummy $=1$ if family took a child care tax deduction last year & 0.698 & 0.807 \\
\hline Subsidy & Dummy $=1$ if family receives child care subsidy & 0.023 & 0.044 \\
\hline Urban & Dummy $=1$ if family lives in urban area & 0.860 & 0.877 \\
\hline Unemprate & Local unemployment rate & 7.095 & 6.282 \\
\hline Centers/Kidpop & Number of centers in states/kids under 14 in state & 0.002 & 0.002 \\
\hline Family/Kidpop & Number of family providers/kids under 14 in state & 0.003 & 0.004 \\
\hline Relnear & Dummy $=1$ if relative available for daycare & 0.174 & 0.175 \\
\hline
\end{tabular}


Table 2: Effects of Regulation on Equilibrium Prices, Hours, and Quality

\begin{tabular}{|c|c|c|c|c|c|c|}
\hline \multirow{2}{*}{ VARIABLES } & \multicolumn{3}{|c|}{ FAMILY: $N=86$} & \multicolumn{3}{|c|}{ CENTERS: $N=114$} \\
\hline & Ln(Price) & Ln(Hours) & Staff/Child & Ln(Price) & Ln(Hours) & Staff/Child \\
\hline REGUL: INSPECTIONS & $\begin{array}{l}0.096^{* *} \\
(7.453)\end{array}$ & $\begin{array}{c}0.056^{* *} \\
(4.236)\end{array}$ & $\begin{array}{l}-0.024^{* *} \\
(3.083)\end{array}$ & $\begin{array}{c}0.029 * \\
(2.325)\end{array}$ & $\begin{array}{c}0.136^{* *} \\
(12.125)\end{array}$ & $\begin{array}{l}-0.009^{* *} \\
(3.321)\end{array}$ \\
\hline REGUL: 1/MXGRSZ & $\begin{array}{l}1.413^{* *} \\
(5.220)\end{array}$ & $\begin{array}{l}-1.779^{* *} \\
(6.353)\end{array}$ & $\begin{array}{l}0.478^{* *} \\
(2.959)\end{array}$ & $\begin{array}{l}1.159 * * \\
(2.701)\end{array}$ & $\begin{array}{l}-0.305 \\
(0.775)\end{array}$ & $\begin{array}{c}0.865 * * \\
(8.884)\end{array}$ \\
\hline REGUL: RTRAINING & $\begin{array}{l}-0.085^{* *} \\
(3.710)\end{array}$ & $\begin{array}{l}-0.097^{* *} \\
(4.093)\end{array}$ & $\begin{array}{l}0.028^{* *} \\
(2.021)\end{array}$ & $\begin{array}{l}-0.318^{* *} \\
(5.449)\end{array}$ & $\begin{array}{l}-0.370^{* *} \\
(6.920)\end{array}$ & $\begin{array}{c}0.002 \\
(0.179)\end{array}$ \\
\hline REGUL: RSTAFF/CHILD & & & & $\begin{array}{l}-0.717 \\
(1.390)\end{array}$ & $\begin{array}{l}-1.434 * * \\
(3.035)\end{array}$ & $\begin{array}{l}-0.435^{* *} \\
(3.714)\end{array}$ \\
\hline SCHOOL & $\begin{array}{c}-0.245^{* *} \\
(-0.025)\end{array}$ & $\begin{array}{c}-0.570^{* *} \\
(12.405)\end{array}$ & $\begin{array}{l}0.232^{* *} \\
(8.737)\end{array}$ & $\begin{array}{c}-0.487^{* *} \\
(12.474)\end{array}$ & $\begin{array}{c}-0.541^{* *} \\
(15.120)\end{array}$ & $\begin{array}{l}-0.079 * * \\
(8.953)\end{array}$ \\
\hline LNFAMINC & $\begin{array}{l}0.071^{* *} \\
(4.276)\end{array}$ & $\begin{array}{l}0.108^{* *} \\
(6.324)\end{array}$ & $\begin{array}{c}-0.147^{* *} \\
(14.915)\end{array}$ & $\begin{array}{l}0.091^{* *} \\
(4.048)\end{array}$ & $\begin{array}{l}-0.092^{* *} \\
(4.484)\end{array}$ & $\begin{array}{l}-0.002 \\
(0.412)\end{array}$ \\
\hline TAXDED & $\begin{array}{c}0.501^{* *} \\
(19.902)\end{array}$ & $\begin{array}{c}0.536^{* *} \\
(20.560)\end{array}$ & $\begin{array}{l}0.043^{* *} \\
(2.837)\end{array}$ & $\begin{array}{l}-0.023 \\
(0.882)\end{array}$ & $\begin{array}{l}0.100^{* *} \\
(4.161)\end{array}$ & $\begin{array}{l}0.060^{* *} \\
(10.026)\end{array}$ \\
\hline SUBSIDY & $\begin{array}{l}0.354^{* *} \\
(5.138)\end{array}$ & $\begin{array}{c}0.139 \\
(1.946)\end{array}$ & $\begin{array}{l}-0.289 * * \\
(7.028)\end{array}$ & $\begin{array}{l}-0.124^{*} \\
(2.224)\end{array}$ & $\begin{array}{l}-0.115^{*} \\
(2.234)\end{array}$ & $\begin{array}{c}0.022 \\
(0.178)\end{array}$ \\
\hline CENTERS/KIDPOP & $\begin{array}{c}-51.255^{* *} \\
(3.507)\end{array}$ & $\begin{array}{l}69.581^{* *} \\
(4.604)\end{array}$ & $\begin{array}{r}-14.576 \\
(1.671)\end{array}$ & $\begin{array}{c}-12.047 \\
(1.380)\end{array}$ & $\begin{array}{c}-12.654 \\
(1.582)\end{array}$ & $\begin{array}{l}-6.079 * * \\
(3.068)\end{array}$ \\
\hline FAMILY/KIDPOP & $\begin{array}{c}-23.981^{* *} \\
(6.721) \\
\end{array}$ & $\begin{array}{l}32.253^{* *} \\
(8.742) \\
\end{array}$ & $\begin{array}{c}7.946^{* *} \\
(3.730)\end{array}$ & $\begin{array}{l}29.383^{* *} \\
(8.421)\end{array}$ & $\begin{array}{l}16.374^{* *} \\
(5.222) \\
\end{array}$ & $\begin{array}{l}-4.013^{* *} \\
(5.168) \\
\end{array}$ \\
\hline R-squared & 0.432 & 0.509 & 0.363 & 0.429 & 0.397 & 0.335 \\
\hline
\end{tabular}

Absolute value of $t$-statistic in parentheses. ${ }^{*}$ and $* *$ indicate significance at the $5 \%$ and $10 \%$ level, respectively. Other variables included, but not reported due to space considerations, include a constant, respondent, child, family, and local area characteristics 


\section{References}

Adams, G., Who Knows How Safe?, (Washington, DC: Children's Defense Fund, 1990).

Epple, Dennis, "Hedonic Prices and Implicit Markets: Estimating Demand and Supply Functions for Differentiated Products," Journal of Political Economy, 1987.

Gormley, W. Jr., "State Regulations and the Availability of Child-Care Services," Journal of Policy Analysis and Management, 1991.

Hayes, C., J. Paimer, and M. Zaslow, Who Cares for America's Children?, (Washington DC: National Research Council, 1990).

Hofferth, S., A. Brayfield, S. Deich, P. Holcomb, and F. Glantz, National Child Care Survey, 1990 (Washington DC: The Urban Institute Press, 1991).

Hofferth, Sandra, and Douglas Wissoker, "Price, Quality, and Income in Child Care Choice," The Journal of Human Resources, 1992.

Joskow, Paul and Nancy Rose, "Effects of Economic Regulation," in The Handbook of Industrial Organization, eds. Richard Schmalensee and Robert Willig, (North Holland: New York, 1988).

Morgan, Gwyen, The National State of Child Care Regulations, (Watertown, MA: Work/Family Directions, Inc. 1986).

Walker, J., "New Evidence on the Supply of Child Care," The Journal of Human Resources, 1992. 